\title{
From Transition to Opportunity: Security through Economic Development \& Institutional Strengthening
}

\author{
Dr. Marios P. Efthymiopoulos \\ President, Strategy International \\ Fr. Visiting Scholar, Center for Transatlantic Relations SAIS, Johns Hopkins University, USA \\ E-mail: Mefthymiopoulos@jhu.edu
}

Dr. Valbona Zeneli

Professor, National Security Studies, Marshall Center, USA

E-mail: valbona.zeneli@marshallcenter.org

Received: April 9, 2012

Accepted: July 25, 2012

Online Published: September 7, 2012

doi:10.5430/rwe.v3n2p29

URL: http://dx.doi.org/10.5430/rwe.v3n2p29

\begin{abstract}
The Economic Crisis affects us all. It does not favor structured long-term development reforms that project stability and growth. Rather it requests for reforms that are necessary to prepare society at large to counter with measures in the short-term, the existing crisis. This paper aims to portray that only long-term development reforms and institutionalized strengthening will effectively counter the fiscal crisis both in the short-term and in the long-term. The article is looking at the dimensions of economic security and development, on the supranationalization of cross border cooperation and it proposes the creation of a Foreign Direct Investment Network through the prism of an Interoperable European Development Network that will be associated both with countries wishing to re-structure or reform as to be more attractive to the Euro-Atlantic Institutions.
\end{abstract}

Keywords: South-Eastern Europe, Euro-Atlantic structures, Foreign direct investment, Interoperable European development network, Financial crisis, Social crisis, Development, Investment, Growth

\section{Preface}

The recent economic crisis has not left anyone unaffected; more importantly so, as it has also affected the region of Southeastern Europe (SEE). Due to current fiscal constraints, there seems to not be enough place to 'maneuver' as to apply any ambitious projects that will deliver security, regional cooperation and growth. The financial crisis does not favor necessary reforms for development that will project long-term stability and prosperity and above all, joined integration of the remainder of SEE states to the Euro-Atlantic structures that is so much wished and expected.

Ambitious projects are those that relate to cross-border, regional and international financial growth, development projects of sustainable effectiveness that provides and guarantees financial security, an sustainable increase in local and national GDP, institutional stability, new employment opportunities, education, research and innovation and overall in the region military security stability as it avoids any future resurrection of historical regional or transnational conflicts.

This article aims to analyze the dimensions of security and development, including the economic dimension of security. Financial security seems to be the new 'buzz phrase' in political and foreign policy affairs. Financial security and prosperity through development projects are expected to resolve partially regional and existing issues and disputes. It increases the percentage of success in delivering the SEE non-integrated states to be fully integrated in the Euro-Atlantic structures rendering the region as secure militarily and political. It also provides a strong future of collaboration, security and stability with those states that are already full members of a single or both Euro-Atlantic structures, namely NATO and the EU. 
Fiscal security cannot be assured or guaranteed today, unless there is a clear long-term projection of an ambitious plan for total growth and development in all fields of a structured community or country. As such this paper will propose the creation of the FDI (Foreign Direct Investment) Network through the prism of the IEDN (Interoperable European Development Network). The success of the IEDN will guarantee also a civil and military security, stability and avoidance of resurrection of old historical trans-boundary issues.

The FDI through the IEDN will guarantee the requirements for fiscal security and growth and will ask for political, military security as also stability in the region. It will be a 'membership road map' towards the entrance to the Euro-Atlantic structures that guarantee peace, security and prosperity.

Per the chapter of this paper, when we refer to financial security we refer to the social, economic, political development that will lower unemployment and poverty; it will enhance civil stability and avoid as was aforementioned possible historical national clashes, as is written in modern $20^{\text {th }}$ century history. A structure for a Foreign Direct Investment Network and a Pan European Interoperable Network will deliver a new strategic plan. It will be innovative, co-operational and multilateral. It will create and combine current existing institutions and will create new ones through a joined conceptual and practical policy for actual deliverables for joined long-term sustainable growth projects for sustainable stability and security.

This chapter requests checking current availability of and for development funds. There is a truly important and increasing need to create, in real-time, new capital and enhance current, for large and mass investment delivering stability in the region through trans-boundary projects rather however than only national, projecting in effect political security and regional financial prosperity. This paper claims in effect the need to go back to the 'drawing boards'; to establish regional growth and development in SEE promising a constructive future to the full integration to the Euro-Atlantic structures, avoiding return to 'nationalization of the region'. Sustainable fiscal growth in the whole of the SEE will ensure financial, stability, security in the region (political and military) and prosperity for the long-term.

\section{Facing Austerity: Foreign Direct Investment in SEE}

The fall of the iron curtain in 1990s, resulted to policy and economic change. All countries of SEE embraced open trade and investment regimes although economic and social liberalization was not an easy process. It was a big shock (Daianu, D., 1997) for countries such as Albania, Romania and Bulgaria; the situation was a little different with the countries of former Yugoslavia, since they were more integrated with western countries in various forms of trade. Although the involvement of SEE countries in international trade has grown substantially from the 1990s, external trade flows have remained limited in many countries. The degree of openness is low compared to Eastern or Western European countries, with Albania having the lowest level and Bulgaria the highest (Note 1).

Since the beginning of the transition process, the main and common objective of the post-communist countries was integration into the global economy. According to western liberal economists, this could be achieved only by large inflows of foreign direct investment (Dunning, J. H., 2006). This was based on the view that rapid growth and successful transition from centrally planned to market economies in Central and Eastern Europe has been due, to a large extent, to successful transformational reforms and foreign investments.

SEE governments encouraged foreign investors to invest and to take part in the privatization process, believing that this would make a critical contribution to growth and development, but would also benefit faster SEE integration (Note 1) into the European Union, which during the last two decades was one of the main objectives for these transition countries.

Foreign Direct Investment (FDI) is an important indicator of the global economic health and stability of a country and is viewed by scholars, economists and politicians, as a major catalyst for development, in particular in developing and transition economies; a strong channel for direct economic growth (through increased employment, exports, income); one of the main sources for private sustainable capital; a vehicle of modernization and technology diffusion; and a driving force for sustainable development and security through as we will later explain the Interoperable European Development Network, (IEDN). Despite all these indicators, it is very important to understand that the benefits of FDI do not accrue automatically and evenly across countries, sectors or local economies. National policies are very important for attracting FDI and reaping their full benefits for development. Even within South-eastern Europe, the distribution of foreign investments is uneven, depending on the local environment, although the countries started in 1990s from similar very low initial levels.

\section{Determining Foreign Direct Investment (FDI)}

There are different theories (Dunning, J. H., 2006) on the factors determining attraction of FDI; location specific attractiveness, political and economical stability, the property and profit tax system, market size and labor 
composition, geographic proximity and quality of financial markets. Today there is evidence that FDI geographic distribution is strongly influenced by host country political and institutional quality because it affects foreign investors' confidence in the domestic investment environment. This is even more important for countries of South East Europe since all of them have experience of instability in the transition process. In some studies, (Kumar, Nagesh \& Pradhan, Jaya Prakash, 2002) it has even been argued that efficient institutions contribute to economic growth more than trade or location.

The linkage between FDI and economic development is complex. Theory and econometric research have shown that foreign investments do not lead automatically to economic growth and development, rather it depends on policy conditions and absorptive capacities such as human resources (Borensztein, E., De Gregorio, J. \& J.W. Lee, 1998), development of the financial market (Balasubramanyam, V.N., Salisu, M. \& Dapsoford, D., 1999), level of openness to trade (Alfaro, Laura, Areendam Chanda, Sebnem Kalemli-Ozcan \& Selin Sayek), and what is more important (Note 3), the quality of the institutions (Zeneli, V., 2011) and of the rule of law in the host countries.

Joseph Stiglitz, the Nobel Laureate, focuses on institutional infrastructure, whose quality is one of the critical determinants of the direction, structure and speed of the transformation process and economic development. Institutions are incentive structures that determine the attitudes and behavior of individuals and organizations owning or accessing resources, capabilities and markets and the ways in which the latter's creation or usage may best meet the requirements of development (North, D., 2005). Institutions create the, milieu within which innovation is undertaken, and they establish the ground rules for interaction between economic actors. In many post- communist economies, the lack of success of economic liberalization and integration into the global economy reflects both the failure to integrate aspects of policy in a systemic way and the difficulty of changing legacy institutions.

Today, the predominant economic theory in international trade is the New Paradigm of Development of Dunning that introduced the concept of institutional assets into the Eclectic Paradigm or OLI Model. As result of new developments in the world economy, the content and the quality of institutions are becoming more important components of both the comparative advantages of firms and location of countries. Because of globalization shifts in economic ideology, recent advantages in technology and new insights into the determinants of growth have shown that however necessary the three determinants (resources, capabilities and markets) for the competitiveness of firms, growth and transformation of countries, they may not be sufficient. For this reason very careful attention needs to be given to the quality, content and origin of institutions, their instruments and mechanisms of implementation.

Southeastern Europe, offers unique opportunities for investors both in terms of emerging markets, strategic position, proximity to Western Europe, natural resources, a flexible and low cost labor force, investment policies, just to name few, but still FDI inflows remained low in the global contexts. Among the main concerns of foreign investors regarding the business climate in the SEE countries (Velkova, E., 2006) have been: political and economic instability, economic underdevelopment due to one of the toughest communist regimes such as in Albania, transformational recession in Bulgaria, wars, political disintegration and ethnic conflicts in the former Yugoslavia, and high levels of corruption in most of these countries.

The 'unfinished' transition process is not favorable to foreign investors because of the gap between formally adopted laws and inability to fully enforce them. Poor infrastructure, problems with the property rights, administrative barriers, non-transparent privatization process, unsatisfactory results in fighting corruption and the thriving informal market, continue to discourage foreign investments and trade. The ethnic conflicts in the region distracted governments from the implementation of economic reforms. Transition mostly takes place in a weak and highly politicized framework, and for this reason efficient and qualitative institutional reforms are very important for these countries.

Extensive corruption in SEE negatively affects growth and development in several ways, by representing and additional cost to the economy, distorting market competition, generating monopolies, eliminating regular and transparent market mechanisms, leading to wrong decision making, poor allocation of resources, loss of legitimacy, less foreign investment attraction, or at least attraction of "non-qualitative" FDI (Note 4).

Foreign investors and international institutions (Note 5) raise also concerns about the quality of education and professional training in SEE. This is related to inadequate public expenditures but also institutional weaknesses in policy formulation and implementation. Key for growth and innovation in transition countries is the development of cognitive skills that are directly associated with the quality of education rather than just numbers of school enrollments (Hanushek, E. \& Woesmann, L., 2010).The lower is the quality of the workforce, the less "qualitative" are the investments, in the sense that they look only for cheap labor with only a short term positive impact. Usually 
these investments are made in mature and less technological industries where the chances of positive spillovers are limited. Brain drain of the most competent young people is another major concern for the region (Note 6).

Advanced econometric studies (Note 7) for the period 1992-2009, point out the importance of FDI in stimulating growth and development in the SEE economies (Zeneli, V., 2011) but at the same time they point out that the quality of the institutional reforms is among the main determinants for their attraction of FDI and reaping full their full benefits in the SEE region (Zeneli, V., 2011a). Financial stability, the quality of institutions, availability of credit to the private sector, degree of competition are measured to potentially directly affect growth in SEE by attracting foreign investors and creating the capacities for the absorption of spillovers. The quality of reforms and institutions is significantly important for the positive effects of FDI in SEE; countries need to have a threshold, a certain level of development of institutions and good governance, to profit from foreign investments.

\section{Economic Downturn and Southeastern Europe}

During the last decade, there optimism in SEE about the macroeconomic stability and economic growth, but unfortunately it was not quite sustainable. The global recession impacted also the countries of SEE to various degrees, and the boom came to an abrupt. At the beginning of 2008, there was the general feeling that the region was escaping from the global crisis and there was optimisms, somehow unwillingness to understand what was happening in the global economy. The truth is that GDP growth in SEE slowed, stopped and even turned negative. Taken as a whole, the regional GDP declined 5, $4 \%$ in 2009 (Note 8). Consumption in the market registered deeper declines, households and firms trimmed spending. The worst hit countries were Bulgaria, Romania and Croatia, also the most developed in the region. Kosovo, the least integrated country avoided the full impact of the crisis (Gashi, P., 2011). It was followed by Albania, which managed to continue to have low growth rate.

These trends compare favorably with those reported from developed economies of the European Union but the very low economic level of development of SEE countries and the catch-up effect of these economies should be taken in consideration in analyzing the situation. The economies of SEE were indirectly impacted by the global crisis, since their banking systems were not directly exposed to the financial crisis; non integration proved to a fortunate event in this case.

The effects of the global crisis spilled over through various channels into SEE, significantly deteriorating the economic and social picture, but economic problems in SEE are related mostly to various institutional and administrative weaknesses, and the global crisis is just an additional explanation for the stagnation of these economies. SEE economies suffer a serious lack of competitiveness. One of the main channels of contagion from the crisis has been the fall of FDI (nevertheless even before the crisis the inflow of FDI was very low in the global context), being one of the main sources which the region has relied on. FDI reached their peak in this region in 2008, in a record of US\$ 32.5 billion (Note 9). The worst indicators were noticed in Romania and Bulgaria, where the foreign investment fell of 50\% in 2009 compared with the same period of 2008 (Note 10) reflecting also the high shares of FDI in finance and real estate.

One major factor for the decline in foreign investments in South East Europe is the fact that they are mostly market seeking, related to the privatization process, and very rarely export-oriented. The quality of investments did not stimulate strong industrial development and sustainable growth through spillover effects, due to the absence of serious presence of green field investments. The decreased flow of FDI in the region does not depend entirely on the lack of global financial resources (which is actually an impediment), rather on the confidence crises of foreign business to invest in risky markets.

Other negative spillovers from the crisis in the SEE region are: the drop in exports (Note 11), especially with European Union; tourism was also negatively impacted in some countries; the decline of remittances from expatriate workers (Note12), which affects not only domestic demand but also the development of small and medium enterprises, being one of the main sources of business capital.

The Greek financial crisis is also likely to severely affect the region in a variety of ways, because of Greece links with the Balkans economy (Kekic, L., 2011). The first negative spillover to the South-eastern Europe would be a political one. The economic and social instability in Greece is going to impact the prospects and timing of some of the countries of SEE for their EU integration, since Greece will not be able to play the role of advocate of the region into EU. Some other negative impacts will be: the risk of financial contagion, since the Greek banks are heavily involved in the region having a share of more than $20 \%$ of the market in the financial sector; and negative impacs on trade, foreign direct investments and remittances. Trade relations with Greece are especially important for Bulgaria, Albania, FYROM and Montenegro and Greek companies are heavily involved in neighboring countries through 
direct investments in the banking and telecommunication sector being either the first or the second main foreign investor (Note 13). There are similarities between Greece and the former communist Balkan countries in terms of institutional effectiveness. Widespread corruption, large informal economies, tax avoidance, rapid expansion of consumer credit, very large current-account deficit (in excess of $10 \%$ of GDP);- are some of the common characteristics in these region.

The lowest point of recession in SEE seems to have been left behind, the region felt less the crisis but will likely estimated to suffer more from the recovery. The first reaction to the crisis, consciously or not, was the tendency of closure of national economies from the global market, lack of integration proved to be fortunate in one sense, but we should understand that this is one of the main barriers for further economic development of the region.

The exact contrary is true, the economic crisis has revealed that integration and economic cooperation in SEE is important for economic growth and development, but also for regional stability and security.

Regional cooperation is important not only for the transition of these countries into European Union, but also for increasing the importance of the region as whole in the global market. SEE Countries cannot compete alone in the global market; they don't have the necessary comparative advantage. The region should offer a unique opportunity for investors through the IEDN both in terms of size of its internal market and as a base for export into Western Europe. With over 50 million people, with growing purchasing power of its consumers, cumulative gross annual income of over $\$ 2$ billion and geographic proximity to Central and Western Europe, SEE should present an attractive destination for market and efficiency seeking serious foreign investors.

Cooperation is important, because it offers the possibility of resolving different regional issues and unpleasant events faced on during the last twenty years, including relapses, wars, and ethnic conflicts and "old" and "new" misunderstandings. These are all which events increased the political instability and consequently the risk for investments, hindering the sustainable economic development of the countries.

Strong economic and political cooperation is possible in South East Europe, because the region shares traits of common history, heritage, cultural and social values. These conditions were reinforced by the incentives from the EU to create a regional cooperation. Greater cooperation reduces instability and political risks, which are the main concern of foreign direct investors in the region. Intensified cooperation could assure smother and faster integration into the EU. Progress should help increase regional competitiveness and achieve sustainable economic and social development. The benefits include increment in trade and investments as well as the potential for the resolution of shared regional issues.

Serious regional economic cooperation in South East Europe began since 1999 with strong involvement of international community, especially EU, where the goal was to establish a wider regional reconstruction and development. Progress has been made in the recent years and with the assistance of EU, SEE has institutionalized to a certain level the economic cooperation on the fields of regional trade, energy, transport and common aviation area.

One of main initiatives was the Stability Pact for South-Eastern Europe (Note14), which in 2008 was gradually replaced by the Regional Cooperation Council, representing a milestone in the regional cooperation in line with the EU goals and objectives and encouraging full ownership of the process by single states by fostering regional economic, political and social cooperation.

EU's Stabilization and Association (Note 15) process is another very important initiative, with three significant aims: the stabilization of the countries of SEE and their transition to the market economy, promotion of regional cooperation and eventual membership to European Union.

Significant accomplishment of cooperation is the new CEFTA 2006, which is a regional FTA signed in 2006 and ratified in 2007. This agreement replaced 32 Free Trade Agreements with one single stable regulatory framework.

With the major objective of establishing an integrated infrastructure market, there has been some progress through the Transport Community Treaty and the Agreement on European Common Aviation Area (ECAA).

\section{West Balkans and $21^{\text {st }}$ Century Integration, Development and Security}

Western Balkan states in the area of SEE remain today to be fully integrated to the Euro-Atlantic structures (Note 16): Others remain to join the EU and others NATO structures and others both. Per the integration of those states the intention of this paper is to put forward a proposal: The remainder of the West Balkan states should establish a collective integration process, a harmonization process (Sanjay Kathuria, 2008), prior and during the integration process to Euro-Atlantic structures, namely EU and NATO integration. As such 'a collective joined integration process for and of all states to the Euro-Atlantic structures is needed to be agreed and implemented'. It seems to be 
the only collective regional as well as logical cooperative choice. Such choice will effectively engage All Balkan states towards a single development goal and will avoid "being permanently relegated to possible renewed ethnic tensions and possible dangerous instabilities" (Pierre, J Andrew, 1999).

A structured and concrete ambitious plan of stability development and growth is consequently needed: A single venture that applies abilities and delivers robust results. Projects of multilateral cooperation shall be needed to be created. It will also need the institutional support and knowledge of structured help from countries of the SEE that are already integrated to the Euro-Atlantic structures (Center for Strategic Research, Turkey, 2012). Reforms shall be implemented including reforms in security sectors, education and culture. Necessary structures will be created thus enabling a preparation for complete and full membership.

What is therefore proposed is a 'development network' a follow up of the SECI (South-east Europe Co-operation Initiative (Note 17)) and the Stability Pact for Southeast Europe (Note 18), that will ensure via multilateral cooperation the creation, of a regional, ambitious project of financial, institutional reform that will establish a concrete collective security and stability prior to their integration to the Euro-Atlantic organizations. It will be of practical and positive cooperation resulting to concrete results. It will be implemented jointly. It will become another step of cooperative formalization but also development, growth, harmonization of institutions and security institutionalization, of practical co-operation that will enhance good neighborly relations as under the agreement of the Thessaloniki Declaration (Note 19). It will be based on the common framework of possible deliverable projects, institutional and infrastructural reform, and innovative constructions and will ensure security prosperity in the region of all SEE.

\section{Strategic Planning \& Development}

The attempt for a joined regional Interoperable Southeast European Development Network (IEDN) will be an opportunity for current member states to harmonize institutions and harmonize national policies with the requests of the Euro-Atlantic organizations. New infrastructures through the FDI will be created and existing will all become, interoperable and interconnected, in every country in the region of SEE. Policies and cooperating methods will be simplified. They will enable a simplest method of deliverables in development projects that will be of practical cooperation and use. Policies and practical projects will positively affect local, regional, national and transnational GDP per person and per country capita.

The IEDN, will project collective financial stability, prosperity, growth and will attract direct investment capital. It will be a network, a political platform with a political and economic framework for the long-term. It will include a memorandum of understanding on cooperation. It will include a conceptual framework and practical application perspective. It will positively counter the existing financial crisis in the region. It will allow the Western Balkans to integrate faster establishing at the same time higher standards than those required. It will request a reformation of current member states institutions and structures that are already members of the Euro-Atlantic Structures. The concept and framework of cooperation shall have a 3-way application: A conceptualization period and joined cooperation, an application period and the lessons learned. The latest shall be the final report on growth, development, investment, stability and reform that should be considered, for the entrance of the western Balkan countries to the Euro-Atlantic structures. It will project practical growth and sustainable development in levels and sectors of the social structures.

The Network will support supranational and long-term policies that will project development. Such programs vary. An example: A new energy road map for regional development (Note 20). Such programs will guarantee amongst others social security and social prosperity. It will provide new and high standards of institutional growth, social and institutional collective development that will allow new countries to have a lighter but also faster integration process in western structures. It will be a form of assessment with not conditionalities but rather applications of projects for development that will also project security stability and growth. Such programs do exist for security development purposes such as the Membership Action Plan (MAP) of NATO (Note 21) or the Partnership for Peace (PfP) (Note 22) Per the EU these are the considered the conditionalities of necessary change for each member that would like to join the EU under the Acquis Communautaire and the negotiations national framework under the enlargement agenda of the European Union (Note 23).

Policy Priorities will be established. Priority shall be given to the economic orientation for growth and development. This equally means in practice as we discuss below the conceptualization of a framework for the attraction and creation of capital for investment, regional and transnational. A new trade zone will be established in the region. It will have a low taxation policy and will attract investment capital. It will lower unemployment rate and will ask for better and higher levels of education. The trading zone in the region of the west Balkans will attract international 
participation. It will request for new global institutions with a local perspective and will harmonize with the conditionalities set-forth by the Euro-Atlantic organizations membership requirements as aforementioned.

The conceptual framework of the IEDN will be an actual road map of development with which the FDI will be made possible and will be also facilitated. It will seek a trans-boundary role of institutional cooperation and security stability and financial prosperity for the region. In practice it will attract mass capital investment that will deliver new infrastructures, services but also individual and collective growth. It will be a concept with a long-term goal that needs to be associated with all governments of the region. The IEDN will request institutional reform in all levels of society, legal, political, security, from future member-states but also countries already members of the Euro-Atlantic structures. The IEDN will promote a harmonization procedure between states in the SEE. As such it is estimated that current financial challenges will be overcome. Harmonized and collective institutions of joined interested will eventually become 'attractive' for the community, national and regional use as they will be of 'international standards'.

A positive reaction to the IEDN in fiscal terms will deliver a political request: A new political security sector reform and a new framework for security stability and prosperity. The IEDN will deliver stability, growth and sustainability through the FDI, fiscally, for the long-term development. The new political security sector reform request that will come forth will deliver a new political road map for harmonization of political issues between states. It will request in real-time an end to security disputes and frozen conflicts, whether bilateral or multilateral on the basis of joined needs to resolve disputes, as fiscal growth and development in such case will be forthcoming and will be a collective asset to all and the 'spoils' will be equally divided.

The IEDN will overall request tackling existing issues of social and security concerns. Such as: migration, unemployment, corruption drug and human trafficking, but also issues of cyber-defense terrorism transnational disputes, human security issues.

The IEDN can be successful through the prism of constant and permanent education. The level of education can be enhance through the work of CEDEFOP (European Centre for the Development of Vocational Training) CEDEFOP, EU. (2009-2010). It will upgrade and increase current transnational quality and quantity of education (OECD, Company ARCADIS, 2004). The IEDN should evaluate the levels of current education and teaching methods, by introducing new ways of teaching methodology through the joint and common use of technology tools and by teaching culture, history and foreign languages instructions and translations in both theoretical but also for practical use ways. Through the platform of permanent and joined education a new generation of leaders but also cooperative individuals in the region will emerge giving a vibrant new society of topical and regional knowledge of culture, history and language. It will also enable exchange of students from school to college and universities that will facilitate primary knowledge.

Current Infrastructure provided should be also evaluated. There is a need of a high level infrastructure from schools to university where students can make use of all tools associated with education, whether this is in the theoretical fields or the human and life sciences. Students should be provided all the necessary tools to increase both their knowledge but also learn new skills associated with the needs of the region in a post-financial crisis era, where sustainable development in all levels of community, countries and regions is evident.

In a sustainable and interoperable new economic reality, a free regional market economy is innovative and cooperative. It provides key assets for reform, innovation and motivation, via the use of technology and knowledge dissemination. It will enable to develop new technology tools in the region. It will offer long-term prosperity and stability. Even more so, through the use of technology new information knowledge can be created, evaluated and applied in societies and societal needs, infrastructures and institutions.

The use of social networks as outsourcing of information and knowledge is used to publicly connect individuals to this day (Note 24). What we propose in such a case is that social networks be associated with the IEDN. Social networks will be able to disseminate all new information to the individuals but also to the states but also institutions. It will simplify methods of communication. It will also become the public outreach directorate of the IEDN. It will be a virtual platform of sharing and exchange of information from the upper level of political conceptualization and will be able to transfer knowledge with the use of a single button to individuals, companies and countries' institutions.

New technology uses with innovative methods will be applied. Such methods will simplify 'societal burdens', our every-day lives, while interconnecting institutions and individuals. It will be entrepreneurial and the method that will 
result will be transferable from business to business, from, institution to institution, from country to country (Note 25).

\section{Concluding Remarks}

In times of austerity and shrinking budgets we have projected the conceptual framework for development and therefore security (fiscal and social). Obviously, there are new opportunities for regional cooperation in different areas: Through the regional trade cooperation such as the IEDN initiative that supports an FDI friendly regional policy throughout the whole region of SEE. Cooperation is therefore practically strengthened, institutions enhanced and new transnational created that will fight corruption, organized crime, poverty and unemployment, through the development of new capital and sustainable investment for productivity and growth.

Through the conceptual framework of the FDI and the IEDN, an action plan will be constructed. It will be absorbed through a pre-membership institutional and infrastructural creation. It will provide strong positive reasons for joined, full and complete integration of the remainder of SEE states in the Euro-Atlantic structures. Full membership for all remainder SEE states, will eventually complete a long-standing puzzle of financial, political, economic and military insecurity, in the region, will strengthen institutional international, transnational organizational effectiveness and will create an era for an enhanced development and security.

Such actions should be supported by the international community. It is our collective duty to support initiatives and policy objectives for the interconnection of our communities through also our joined membership in true international organizations and collective security alliances.

Membership to the structures will therefore eventually be granted. It is a matter of time as both sides (members and non-members) wish it. Their entrance to the institutional structures will provide a clear picture of security stability, development perspective and growth projection. It will have a practical application in security affairs will result to a security sector reform will create new institutions and infrastructures. It will have a positive impact factor towards social change (current unemployment high rates, poverty, and will impact current the current global economic crisis). It will also have an impact to the European Union's financial crisis and the crisis within the Eurozone as new coming countries will be requested to evolve, to invest and to develop their public and private assets.

Time is of essence. It is the only remaining obstacle for countries wishing to join the Euro-Atlantic structures; Time will guarantee the solution to all current obstacles that require negotiations direct or indirect. Issues need to be overcome and they will eventually be. Issues are included and known in all international or bilateral relations amongst states of the region. These issues have historically proven to create a defect resulting to instability and insecurity, conflict, war, underdevelopment and therefore poverty, migration, constant fiscal crisis, low GDP local and national GDP and low levels of education, research and innovation.

The entrance to the Euro-Atlantic structures will create a new secure and stable 'chess board' for growth and development. It will guarantee sustainable development, institutional cross-border interoperability, practical cooperation fiscal and military security. SEE countries desire for NATO and EU membership. It is an important political aim. It will keep the countries disengaged from the game of nationalist internalized politics, insecurity and underdevelopment in the region.

Once integration is to the structures is concluded, it will end a long-history of former divisional lines between states, with technical and official boundaries in the European continent. It will create a new balance of policy, power and security. It will be based on new alliance forms, with restructured policies. It will be based on joined and supranational interests and needs; at a time of regional but also global security challenges that now exceed and extent beyond the Euro-Atlantic boundaries, the policy and willingness of all members-states to strong Euro-Atlantic organizations and the presence of those institutions will guarantee sustainable growth, stability, security and financial prosperity.

Participation reflects in practice a 'pure and just form', a wishful and applicable thinking, a true willingness for multilateralism through concrete and constructive cooperation in all aforementioned sectors, via the use of creative ideas. It will offer credible deliverables for honest and truthful growth, development and therefore security stability in both financial and political/military terms.

change: a. is inevitable, even more so when change seems and is of positive nature, $b$. growth and investment is a 'must' towards stability, prosperity, towards actual integration to the Euro-Atlantic structures.

Civil and financial transformation in the region of southeastern Europe over the last years and in the years to come, will result to concrete structures of institutional building, economic efficiency, investment and growth. It will 
stabilize the region, resolve frozen conflicts but also create a neighboring policy that does more, that is innovative in its practicability of joined or cross-border projects, that is credible and delivers positive outcomes.

Surely, a new regional balance of power and alliances between regional and all-European or Euro-Atlantic states, based on interests will be re-created. Nonetheless, they will and should not conflict with multilateral supranational Euro-Atlantic joined interests. Whether new balances and new alliances are regional or European in the periphery of Southeast European States, supranational interests will always be projected and sustained, guaranteeing security and stability.

\subsection{Proposals}

Countries can firstly strengthen the regional trade cooperation. Intra-regional trade levels are low, very much below potentials, in spite of a new CEFTA 2006 (agreement between the countries that has substantially lowered the tariffs for import-export. Recently, governments have had success in easing administrative procedures to imports and exports, but they still lagging behind others and remains nevertheless a huge potential. Trade is dominated by commodities; intra-industry trade remains very low. The main problems still lie on non-tariff barriers, on long administrative procedures; just to bring the example of two very particular "tariffs" in the region; namely time tax and bribe tax. Countries of SEE should aim to achieve as soon as possible complete trade liberalization and final elimination of tariffs and quotas. Custom and trade regulations should be harmonized and adapted to European standards. This would lower transaction costs and develop comparative advantages of countries for creating economies of scale. All these will facilitate intra-regional trade and make the region more attractive. It will also help the resolution of a number of issues on regional projects, which need a common overall infrastructure. CEFTA agreement offers a unique platform for governments to solve problems of non-tariff barriers and work together to decrease obstacles.

Second, SEE countries should continue to focus on policies and reforms that promote institutional development and develop a friendly environment for the attraction and targeting of "qualitative" foreign investments, in order to start a new cycle of development. Consistent political stability, efficient law enforcement, healthy fiscal and monetary policies and strong anti-corruption reforms could contribute not only for the attraction of "qualitative" foreign investments but also for boosting longer and sustainable positive effects for growth and development. New and effective should be able to direct the inflows of FDI to the sectors that augment domestic investment and lead to sustainable economic growth.

Third, the existence of rule of law and efficient and transparent public administration are preconditions for business development and FDI inflows. In this respect, countries of SEE should increase their cooperation on the fight against corruption and organized crime which are also the main concerns of European Union. Governments should show results and implement the very necessary and expected reforms in the fields of public administration, judiciary, and competition policy. Regional cooperation-, in information sharing and exchange of best practices-, is crucial precondition for success.

Fourthly, interaction between research, education and innovation can be a driving force for economic development in SEE. Countries of the region should establish and coordinate their programs to foster a more qualitative education and training system to preparing the young generations for new challenges. Strengthening education, training, research and innovation policies through reforms, make preconditions for stronger investment in $R \& D$. There is a general need to improve scientific structure in the Region, attract experts, reduce brain drain.

The IEDN network and projection planning through the FDI will not be a static force. It will be network and policy framework that will project a forced application and positive reaction to sustainable development and long-term growth.

The network will be of long-term applicability, research and development that will be established in real-time and will offer more than already offered, especially when at a time of financial crisis solutions are seeked.

The IEDN will grant an FDI program for the total of the region of Southeastern Europe, something that is not there yet: Security, stability and prosperity. It will aim to overcome all obstacles. It will aim to interconnect and overcome all divisional obstacles. It will create a new and economic efficiency reality. A new capacity of all southeastern nations that will ensure needs of populations, societies, cultures and civilizations along with national interests.

The IEDN will address all current consequences of the economic crisis but will also question it by promoting a new, balanced and innovative program, a framework of growth in all sectors that will be applied into.. It should be able to direct the inflows of FDI to the sectors that augment domestic investment and lead to sustainable economic growth. 
The FDI through the IEDN will meet all human security standards and necessities and needs of the region. It will complement efforts made currently by individual states to overcome all institutional and legal frameworks and join western institutions, the Euro-Atlantic structures.

The IEDN does not endorse financial mistakes but rather could be a key solving institution that will address real issues, in real-time, seeking real-solving solutions, with the minimum financial cost at a supranational regional level, while introducing burden-sharing to all Southeast European countries. The network will familiarize Southeast European states with interconnected work.

Strong cooperation is important through the qualitative FDI attraction for restoring and increasing the competitiveness of the region in these very difficult after-crisis times. The speed of the recovery in SEE will depend on how fast, will lessons from the crisis be learned, how good new policies will be designed, coordinated, introduced and implemented to cope with the new realities and provide a financial security surplus that will project stability and growth.

\section{References}

Alfaro, Laura, Areendam Chanda, Sebnem Kalemli-Ozcan, \& Selin Sayek. FDI and Economic Growth: The Role of Local Financial Markets. Harvard Business School. Working Paper 01-083.

Balasubramanyam, V.N., Salisu, M., \& Dapsoford, D. (1999). Foreign Direct Investment as an Engine of Growth. Journal of International Trade and Economic Development, 8(1), 27-40.

Borensztein, E., De Gregorio, J., \& J.W. Lee. (1998). How does foreign investment affect growth? Journal of International Economics, 45.

CEDEFOP, EU. (2009-2010). Structures of Education and Training Systems in Europe, Liechtenstein. [Online] Available: http://eacea.ec.europa.eu/education/eurydice/documents/eurybase/structures/041_LI_EN.pdf

Center for Strategic Research, Turkey. (2012, January). Article by Ambassador (retd.) Ali Hikmet Alp: The southeast Europe Co-operation Process: An Unspectacular, indigenous, regional cooperation scheme. [Online] Available: http://sam.gov.tr/tr/wp-content/uploads/2012/01/Ali-Hikmet-Alp.pdf

Daianu, D. (1997). Explaining shock in post-communist economies. Economies in transition.

Dunning, J. H. (2006). Towards a New Paradigm of Development: Implications for the Determinants of International Business Activity. Transnational Corporations, 15(1), 173-228.

Gashi, P. (2011). The global economic crisis and Kosovo. LSEE.

Hanushek, E., \& Woesmann, L. (2010, April). The Economics of International Differences in Educational Achievement. National Bureau of Economic Research (NBER), Working paper 15494.

Kekic, L. (2011). The Greek crisis- the threat to neighboring Balkan economies. LSEE.

Kumar, Nagesh, \& Pradhan, Jaya Prakash. (2002). Foreign direct Investments and Economic Growth in Developing Countries: Some empirical Explorations and Implications for WTO negotiations on Investment. RIS Discussion Paper No27/2002. New Delphi India.

North, D. (2005). Understanding the process of economic change. Priceton University Press.

OECD, Company ARCADIS. (2004). Public Administration Reform Capacity-Building in the SAP (Stabilisation and Association Process Stabilisation and Association Process) Countries Towards a Regional School for Higher Education for Public Administration Reform (SHEPAR), the case for the Western Balkans. [Online] Available: http://www.oecd.org/dataoecd/37/5/37969472.pdf

Pierre, J Andrew. (1999, September). De-Balkanizing the Balkans: Security and Stability in Southeastern Europe. Special Report No. 54, Institute of Peace.

Sanjay Kathuria, (Ed). (2008). Western Balkan Integration and the EU: An Agenda for Trade and Growth. The World Bank.

Velkova, E. (2006). Integration of South-East Europe in the EU: Corruption, Foreign Direct Investment and Development. Harvard European Law Working Paper No.3.

Zeneli, V. (2011). Foreign Direct Investment and Economic growth in South-east European countries. Ph.D. Dissertation.

Zeneli, V. (2011a). The determinants for the attraction of FDI in South-east European countries. The role of 
Institutions. Ph.D. Dissertation.

\section{Notes}

Note 1. International Monetary Fund, 2008

Note 2. Bulgaria and Romania are members of the European Union.

Note 3. This is according to the personal opinion of the author of the article.

Note 4. Pitelis, C. N., Economic Integration through Foreign Direct Investment in (the Less Favored Countries of) Central and Eastern Europe and Impact on the (Less Favored Countries of the) European Union, ACE Project No 94-0719-R, 1997.

Note 5. OECD Investment Reform Index, 2006 and EFA Global Monitoring Report (2009) UNESCO.

Note 6. EFA Global Monitoring Report (2009) UNESCO

Note 7. The study aimed to explore the relationship between foreign direct investment and economic growth in South East Europe. The panel dataset covered 8 countries (Albania, Bulgaria, Romania, Croatia, FRY Macedonia, Bosnia \& Herzegovina, Serbia and Montenegro) over the period 1992-2009. GMM (Generalized Method of Moments) panel data system techniques were used for the analysis. Major growth factors are taken in consideration in this analysis as initial income per capita in the host country, human capital, trade, inflation, governments spending, domestic investments, credit to the private sector, remittances, quality of institutions and privatization process (the inflows of FDI were divided into Greenfield and Privatization-related FDI) (Zeneli, 2010b)

Note 8. EBRD Transition Reports 2011.

Note 9. UNCTAD

Note 10. In Bulgaria FDI per capita in 2008 was 1290 \$, in 2009 fell to 592 \$. Source: UNCTAD database.

Note 11. Export markets in EU countries (especially Germany, Italy, Greece and Austria) dropped sharply in 2009 with some signs of stabilization in 2010. Countries which suffered more are: Bosnia and Herzegovina, FRY Macedonia, Romania and Serbia in the steel industry and aluminum; Romania in the car industry; and other countries in their textile industries

Note 12. Especially in the cases of Albania, Croatia and Romania, EIU statistics.

Note 13. Economist Intelligence Unit

Note 14. The Stability Pact for South Eastern Europe. http://www.stabilitypact.org

Note 15. The European Commission, Policy on Enlargement, http://ec.europa.eu/enlargement

Note 16. Strategic Concept of NATO: Active Engagement Modern Defense, $(19$ November 2010) http://www.nato.int/cps/en/natolive/official_texts_68580.htm

Note 17. Formerly SECI currently SELEC (Southeast Europe Law Enforcement Center) http://www.secicenter.org/ The objective of SELEC, within the framework of cooperation among Competent Authorities, is to provide support for Member States and enhance coordination in preventing and combating crime, including serious and organized crime, where such crime involves or appears to involve an element of trans-border activity.

Note 18. The Southeast Europe Stability Pact: http://www.stabilitypact.org/

Note 19. In Petraj Simic: Yugoslavia and regional Cooperation, Institute of International and Political Studies University of Beograd, Međunarodni problem 1998, Vol 50 br. 1, pp 23-42, he refers to the Thessaloniki Declaration of 1997 on good neighborly relations Thessaloniki Declaration on Good Neighborly Relations, Stability, Security and Cooperation in the Balkans. Eurobalkans, Athens, br. 2627, str. 36.

Note 20. Lately there is a try over official meetings and conference to re-establish relations amongst states in the Balkans to establish a new road map and market for energy development. For more information see the upcoming conference on May $2012 \mathrm{http}: / / \mathrm{www} .0 i l g a s c o n f e r e n c e s . c o m$

Note 21. Membership Action Plan: http://www.nato.int/cps/en/natolive/topics_37356.htm

Note 22. The Partnership for Peace Program of NATO: http://www.nato.int/issues/pfp/index.html

Note 23. European Union Enlargement process, Commission of the European Union, $\mathrm{http}: / /$ ec.europa.eu/enlargement/enlargement_process/accession_process/how_does_a_country_join_the_eu/negotiati ons_croatia_turkey/index_en.htm 
Note 24. Eytan Bakshy, Itamar Rosenn, Cameron Marlow, Lada Adamic, (2012), The Role of Social Networks in Information Diffusion, In Proceedings of ACM WWW 2012, April 16-20, 2012, Lyon, France

http://arxiv.org/pdf/1201.4145v2.pdf

Note 25. Center for Technology and Research http://www.certh.gr/

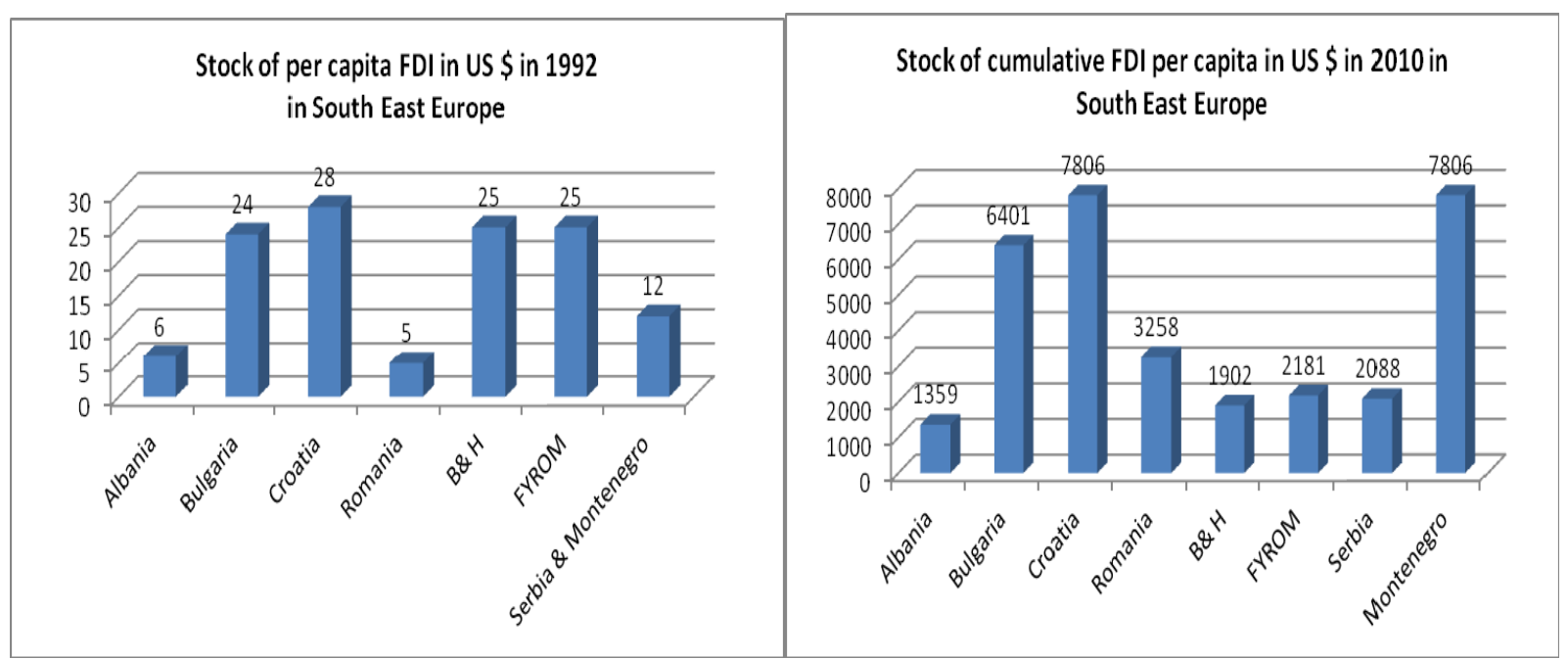

Chart 1. Stock of FDI per capita in USD into South-eastern Europe in 1992 and 2010

Geographic distribution of FDI is influenced mostly by the host country political and institutional quality. Source: UNCTAD 